\title{
Aplikasi Kompos dan Arang Aktif Sebagai Bahan Amelioran di Tanah Berpasir Terhadap Pertumbuhan Tanaman Caisim (Brassica juncea $\mathrm{L}$.
}

\section{Application of Compost And Activated Charcoal as Ameliorant Material in Sandy Soil For The Growth Of Mustard Plants (Brassica juncea L.)}

\section{Priyadi*, Jamaludin, dan Windu Mangiring}

STIPER Dharma Wacana Metro

*E-mail : priyadigege@ymail.com

\begin{abstract}
One of the efforts in sandy soil utilization is to add ameliorant material. The addition of ameliorant material can use compost that plays an important role in improving the physical, chemical and biological properties of the soil. The purpose of this study was to determine the effect of compost and activated charcoal as ameliorant material on sandy soil to the growth of mustard plant (Bressica juncea L). The study was conducted at Greenhouse of STIPER Dharma Wacana Metro, while soil analysis was conducted in Taman Bogo Soil Research Laboratory. The results showed that the use of ameliorant material in the form of activated charcoal and compost can improve the sandy soil properties as indicated by the increase of $\mathrm{pH}$, moisture content, $\mathrm{C}$-organic, and $\mathrm{N}$-total. The highest effect of growth was shown in the treatment of PK that is 9.86 gram. While, the highest growth of plant roots is shown in 1.07 gram of PKA treatment. In general, the use of ameliorants in this study has a good effect in the change of sandy soil properties and growth in mustard plants.
\end{abstract}

Keywords:ameliorant, compost, mustard, sandy soil.

Disubmit : 17 Januari 2018 ; Diterima: 07 April 2018 ; Disetujui : 07 Mei 2018

\section{PENDAHULUAN}

Pasir merupakan bagian dari fraksi tanah yang memiliki sifat - sifat yang sangat sulit jika dimanfaatkan sebagai media pertumbuhan tanaman. Sifat pasir yang porous dan memiliki daya menahan air sangat rendah merupakan salah satu kendala dalam pemanfaatan tanah - tanah dengan kandungan pasir yang tinggi. Selain itu, pasir juga cenderung memiliki kapasitas tukar kation yang rendah, sehingga unsur hara yang ada pada tanah berpasir lebih cepat hilang dan tercuci.

Salah satu jenis tanah dengan kandungan pasir yang tinggi adalah tanah regosol. Tanah ini memiliki ciri antara lain adalah berstruktur kasar, tidak mempunyai horizon diagnostik dan berkadar fraksi pasir 60 persen atau lebih pada kedalaman antara 25 dan $100 \mathrm{~cm}$ (Balai Penelitian dan Pengembangan Pertanian, 2006). Selain itu, tanah berpasir juga memiliki kandungan bahan organik rendah, daya adsorb rendah, KTK rendah, permeabilitas tinggi dan memiliki kepekaan terhadap erosi yang besar (Rachim and Arifin, 2013). Tanah ini biasanya banyak dijumpai pada bahan induk abu volkan, mergel dan bukit pasir pantai. Tanah tanah dengan kandungan jumlah pasir yang tinggi tentunya perlu adanya usaha yang lebih besar untuk dapat memanfaatkannya. Oleh karena itu, perlu dilakukan usaha untuk dapat mengurangi permasalah tersebut. Salah satu upaya yang dilakukan adalah dengan penambahan bahan amelioran ke dalam tanah. 
Upaya penambahan bahan amelioran antara lain dengan menggunakan kompos. Kompos merupakan bahan amelioran organik yang mempunyai peranan penting dalam memperbaiki sifat fisik, kimia dan biologi tanah. Peranan terhadap fisik tanah antara lain sebagai bahan perekat antar partikel tanah untuk bersatu menjadi agregat tanah, memperbaiki struktur tanah, meningkatkan porositas tanah, meningkatkan kemampuan tanah dalam menahan air (water holding capacity), dan menurunkan laju erosi tanah (Atmojo, 2003). Penambahan bahan amelioran diharapkan dapat merubah struktur tanah dari berbutir tunggal menjadi bentuk gumpal, sehingga meningkatkan derajat struktur dan ukuran agregat atau meningkatkan kelas struktur dari halus menjadi sedang atau kasar (Scholes et al., 1994).

Selain itu, pemberian bahan organik seperti kompos dapat memberikan konstribusi yang nyata terhadap KTK tanah. Dimana sekitar 20 - 70 \% KTK tanah umumnya bersumber pada koloid, sehingga terdapat korelasi antara bahan organik dengan KTK tanah (Stevenson, 1982). KTK bahan organik diperoleh dari muatan negatif humus. Sumber utama muatan negatif humus sebagian besar berasal dari gugus karboksil dan fenolik (Brady, 1990). Hasil penelitian (Cahyani, 1996) menunjukkan bahwa penambahan jerami 10 ton ha $^{-1}$ pada Ultisol mampu meningkatkan $15,18 \%$ KTK tanah dari 17,44 menjadi 20,08 $\mathrm{cmol}^{(+)} \mathrm{kg}^{-1}$.

Berkaitan dengan tanah pasir yang memiliki kemampuan dalam menahan air yang rendah, maka selain penambahan bahan organik penelitian ini juga memanfaatkan arang aktif. Arang aktif atau karbon aktif adalah arang aktif yang konfigurasi atom karbonnya dibebaskan dari ikatan dengan unsur lain serta rongga atau porinya dibersihkan dari senyawa lain atau kotoran, sehingga permukaan dan pusat aktifnya menjadi luas atau meningkatkan daya adsorbsi terhadap cairan dan gas. Melihat kemampuan dari arang aktif ini maka diharapkan tanah berpasir yang digunakan sebagai media tanam dapat mempertahankan air melalui daya adsorpsinya yang besar. Selain itu arang aktif bersifat higroskopis sehingga dapat mengurangi pencucian yang terjadi pada tanah pasir. Berdasarkan hal tersebut penelitian ini dilakukan untuk mengetahui pengaruh pemberian kompos dan arang aktif sebagai bahan amelioran terhadap sifat tanah pasir serta pertumbuhan dan hasil tanaman caisim (Brassica juncea L.)

\section{METODE PENELITIAN}

Penelitian dilaksanakan di Rumah Kaca yang terletak di Kebun Percobaan milik STIPER Dharma Wacana Metro, sedangkan analisis tanah dilakukan di laboratorium Balai Penelitian Tanah Taman Bogo Lampung. Pelaksanaan kegiatan dilaksanakan bulan Agustus sampai dengan Oktober 2016. Rancangan percobaan penelitian dilakukan pada polybag dengan menggunakan rancangan acak kelompok (RAK) yang terdiri dari 4 perlakuan dan 3 ulangan. Dengan demikian jumlah satuan percobaan yang digunakan adalah 12 satuan percobaan. Adapun perlakuan yang diberikan yaitu P (Pasir $5 \mathrm{~kg}$ ); PA (Pasir $5 \mathrm{~kg}+$ Arang aktif dosis

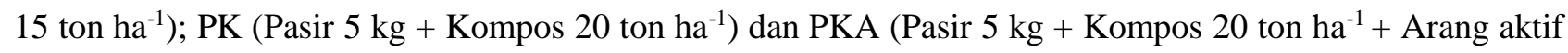
dosis 15 ton ha $\left.^{-1}\right)$.

Untuk mengetahui pengaruh pemberian kompos dan arang aktif, dilakukan pengamatan terhadap tanaman dan tanah. Parameter yang diamati pada tanaman adalah berat basah dan berat kering tanaman yang dilakukan pada akhir setelah tanaman dipanen. Sedangkan parameter yang diamati pada tanah adalah $\mathrm{pH}$, kadar air, N - Total, dan C-organik yang dilakukan setelah tanaman dipanen. Analisis tanah dilakukan untuk setiap perlakuan secara komposit dari 3 ulangan. Data hasil pengamatan kemudian dilakukan analisis menggunakan microsft excel.

\section{HASIL DAN PEMBAHASAN}

Pertumbuhan Tanaman Caisim. Pertumbuhan tanamanan merupakan hasil dari berbagai proses fisiologi yang melibatkan beberapa faktor antara lain genotipe dengan faktor lingkungan. Salah satu faktor yang sangat berperan yaitu pemberian nutrisi pada tanaman. Nutrisi untuk tanaman tersebut dapat diperoleh dari sumber bahan organik. Pemberian bahan organik dalam penelitian ini berupa kompos, menunjukkan 
Priyadi dkk: Aplikasi Kompos dan Arang Aktif Sebagai Bahan Amelioran di Tanah Berpasir...

pengaruh yang signifikan terhadap pertumbuhan tanaman caisim. Pengaruh pemberian kompos terhadap pertumbuhan dan hasil tanaman caisim (Brassica juncea L.) ditunjukkan pada Gambar 1.

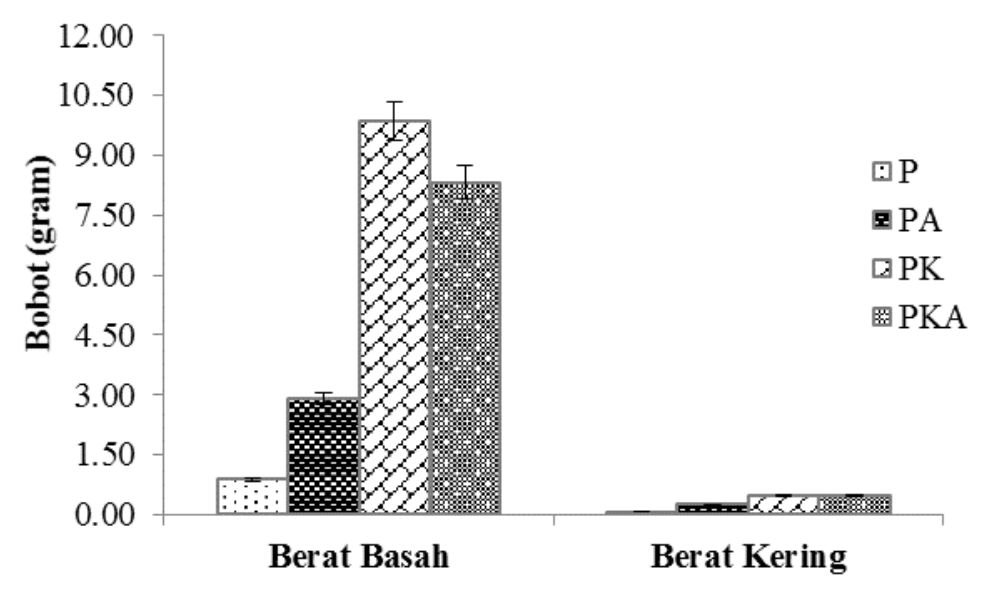

Gambar 1. Pengaruh Pemberian Kompos dan Arang Aktif Sebagai Bahan Amelioran Terhadap Bobot Daun Tanaman Caisim (Brassica juncea) pada Umur 40 HST.

Dari hasil analisis dapat diketahui bahwa perbedaan yang nyata terlihat antara perlakuan pemberian kompos dan arang aktif dengan tanpa pemberian kompos dan arang aktif terhadap bobot daun tanaman caisim (Brassica juncea). Sedangkan Gambar 2 menunjukkan perbedaan antara perlakuan pemberian kompos dan arang aktif terhadap bobot akar tanaman caisim (Brassica juncea) pada umur 40 HST.

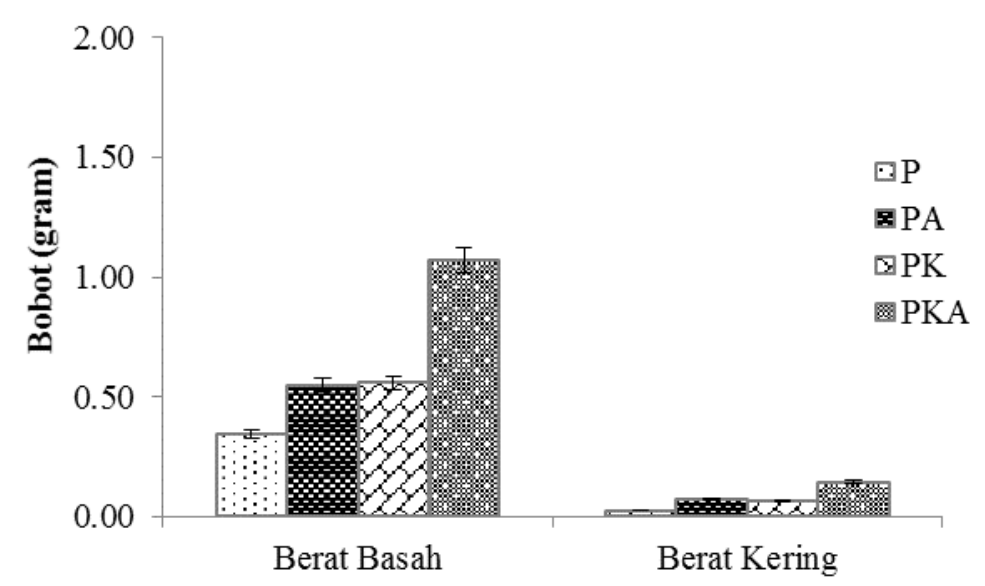

Gambar 2. Pengaruh Pemberian Kompos dan Arang Aktif Sebagai Bahan Amelioran Terhadap Bobot Akar Tanaman Caisim (Brassica juncea) pada Umur 40 HST.

Secara umum pertumbuhan tanaman caisim terlihat tidak begitu optimal, namun perbedaan cukup jelas terlihat antara masing - masing perlakuan. Pertumbuhan tanaman dipengaruhi oleh berbagai faktor, antara lain adalah sifat fisik dan kimia media maupun dari kondisi lingkungannya. Sifat media tumbuh tanaman berupa pasir diketahui selain sulit mempertahankan air, pasir juga memiliki daya serap terhadap panas yang cukup tinggi. Penyerapan yang tinggi terhadap panas dan sifat pasir yang porous menyebabkan tanah menjadi sangat kering, secara tidak langsung hal mempengaruhi pertumbuhan tanaman caisim menjadi tidak optimal. Penelitian (Farooq et al., 2009) mengungkapkan bahwa keadaan stress karena kekurangan air pada tanaman menyebabkan menurunnya ukuran daun, perluasan batang, proliferasi akar, mengganggu hubungan air dengan tanaman dan mengurangi efisiensi dalam penggunaan air.

Hasil analisis menunjukkan bahwa perlakuan pemberian bahan amelioran berupa kompos maupun arang aktif dan kombinasinya terlihat memberikan pengaruh yang cenderung lebih tinggi dibandingkan tanpa 
pemberian bahan amelioran. Pemberian kompos sebagai bahan amelioran secara dijelaskan dapat meningkatkan produksi pada tanaman dan memperbaiki sifat tanah antara lain konduktivitas listrik tanah, peningkatan $\mathrm{pH}$ dan beberapa konsentrasi unsur yang berkontribusi bagi tanamanan yaitu $\mathrm{P}$ dan $\mathrm{NO}_{3}-\mathrm{N}$ (Eghball et al., 2004). Hal ini dapat disimpulkan bahwa pemberian bahan amelioran pada tanah pasir sangat diperlukan untuk menyediakan media tumbuh yang baik bagi tanaman. Pemberian bahan amelioran berupa kompos pada masing-masing perlakuan menunjukkan bahwa kompos cenderung lebih tinggi dibandingkan dengan pemberian arang aktif ataupun tanpa perlakuan. Hal ini menjelaskan bahwa pemberian kompos dapat memperbaiki sifat fisik tanah dan juga memperbaiki sifat kimia dari tanah pasir. Senada dengan yang diungkapkan (Gusta et al., 2014) bahwa penggunaan media kompos dari sabut kelapa sawit sebagai media tanam nyata meningkatkan terhadap bobot kering pada pembibitan tanaman kelapa sawit.

Pemberian kompos diketahui dapat meningkatkan kandungan $\mathrm{K}, \mathrm{Ca}$ dan $\mathrm{Mg}$ dalam media. Peningkatan kandungan $\mathrm{K}$, Ca dan Mg pada media tanam sebanding dengan peningkatan kompos yang diberikan. Kandungan $\mathrm{K}, \mathrm{Ca}$, dan Mg madia tanam semakin tinggi dengan peningkatan dosis kompos yang diberikan. Hal ini sesuai dengan yang di ungkapkan (Mandey et al., 2010) bahwa kompos aktif organik yang dihasilkan memberikan unsur hara $\mathrm{N}, \mathrm{P}, \mathrm{K}, \mathrm{Ca}, \mathrm{Mg}$, mempertahankan kadar air dan meningkatkan $\mathrm{pH}$. Pemberian kompos dengan berbagai dosis dapat meningkatkan KTK tanah, sejalan dengan yang dikemukakan oleh (Atmojo, 2003) bahwa bahan organik berperan dalam meningkatkan KTK dan KB tanah.

Perlakuan arang aktif tidak menunjukkan perbedaan yang nyata terhadap parameter yang diamati. Hal ini terjadi karena pemberian arang aktif hanya berperan untuk mempertahankan kandungan air yang ada di dalam media pasir tersebut. Arang aktif tidak mampu menyumbangkan unsur hara seperti halnya pada perlakuan kompos. Selain itu, arang aktif yang besifat higroskopis ini mungkin mengikat unsur-unsur hara yang dibutuhkan oleh tanaman. Seperti yang diungkapkan (Prastiwi, 2013) bahwa arang aktif dapat digunakan untuk mengadsorpsi unsur hara mikro yang ditambahkan. Adanya adsorpsi akibat penambahan arang aktif dapat mempengaruhi pertumbuhan pada tanaman caisim menjadi lebih rendah seakan-akan terjadi defisiensi unsur hara yang terlihat dari penampakan daun tidak normal. Beberapa penelitian juga menjelaskan bahwa arang aktif memiliki potensi untuk menyerap nutrisi. (Mizuta et al., 2004) mengungkapkan bahwa arang aktif yang dibuat dari bambu dengan suhu $900{ }^{\circ} \mathrm{C}$ mampu menyerap sekitar $1,2 \mathrm{mg} \cdot \mathrm{g}^{-1}$ unsur hara nitrat. (Yao et al., 2012) menjelaskan bahwa arang aktif secara efektif dapat mengadsorpsi nitrat sebesar 3,7\%, amonium sebesar $15,7 \%$ dan fosfat sebesar $3,1 \%$.

Selain itu, pengaruh pemberian arang aktif tidak menunjukan pengaruh yang signifikan karena jumlah yang diberikan sebagai bahan amelioran masih jauh dari kebutuhan. Seperti yang sudah banyak diketahui bahwa pemberian aplikasi bahan amelioran dibutuhkan dalam jumlah yang cukup besar, jika dibandingkan dengan jumlah aplikasi yang dilakukan dalam percobaan masih sangat rendah. Pemberian amelioran berupa arang aktif juga lebih baik jika digunakan untuk tanaman - tanaman tahunan agar pengaruhnya lebih terlihat jelas, sedangkan pada percobaan tanaman yang digunakan adalah caisim yang merupakan tanaman semusim sehingga pengaruhnya tidak terlihat nyata. Hal lain juga berkaitan dengan hasil analisis $\mathrm{pH}$ tanah yang menunjukkan bahwa dari perlakuan bahan amelioran ternyata dapat meningkatkan $\mathrm{pH}$. Peningkatan $\mathrm{pH}$ yang terjadi dapat menyebabkan unsur - unsur hara mikro yang dibutuhkan oleh tanaman tidak dapat diserap karena terjadi pengendapan seiring peningkatan $\mathrm{pH}$ serta tidak larut sehingga tidak dapat diserap oleh tanaman.

Analisis Sifat Media Tumbuh Tanaman. Hasil analisis berbagai sifat media tumbuh tanaman berupa $\mathrm{pH}$, kadar air, C-organik, dan $\mathrm{N}$-total $\mathrm{pH} \mathrm{H}_{2} \mathrm{O}$ menunjukkan hasil yang nyata terhadap perlakuan pemberian bahan amelioran (Tabel 1). Tabel 1 menunjukkan bahwa perlakuan pemberian bahan amelioran dapat meningkatkan $\mathrm{pH}$, dimana peningkatan yang cenderung lebih tinggi terjadi pada perlakuan aplikasi arang aktif dan kombinasi kompos dan arang aktif. Penelitian (Yamato et al., 2006) memberikan informasi bahwa penggunaan arang aktif dapat meningkatkan $\mathrm{pH}$ tanah, kadar $\mathrm{N}$ total, $\mathrm{P}_{2} \mathrm{O}_{5}$ tersedia, KTK, jumlah kation 
Priyadi dkk : Aplikasi Kompos dan Arang Aktif Sebagai Bahan Amelioran di Tanah Berpasir...

dapat dipertukarkan dan kejenuhan basa, serta menurunkan kadar $\mathrm{Al}^{3+}$ dapat dipertukarkan. Adanya sifat dari arang aktif tersebut yang dapat mempertukarkan kation, kemungkinan dapat juga menyerap ion-ion $\mathrm{H}$ yang merupakan sumber kemasaman sehingga $\mathrm{pH}$ cenderung menjadi meningkat.

Tabel 1. Hasil Analisis Media Tanah Pasir dari Berbagai Jenis Perlakuan.

\begin{tabular}{lcccc}
\hline Perlakuan & $\mathrm{pH} \mathrm{H}_{2} \mathrm{O}(1: 2)$ & $\begin{array}{c}\text { Kadar Air } \\
(\%)\end{array}$ & $\begin{array}{c}\mathrm{C}-\text { Organik } \\
(\%)\end{array}$ & $\begin{array}{c}\mathrm{N}-\text { total } \\
(\%)\end{array}$ \\
\hline $\mathrm{P}$ & $6.44 \mathrm{a}$ & $0.15 \mathrm{a}$ & $0.07 \mathrm{a}$ & $0.03 \mathrm{a}$ \\
$\mathrm{PA}$ & $7.09 \mathrm{c}$ & $0.26 \mathrm{~b}$ & $0.16 \mathrm{~b}$ & $0.04 \mathrm{ab}$ \\
$\mathrm{PK}$ & $6.80 \mathrm{~b}$ & $4.33 \mathrm{c}$ & $2.61 \mathrm{c}$ & $0.08 \mathrm{c}$ \\
PKA & $7.30 \mathrm{~cd}$ & $3.65 \mathrm{~d}$ & $2.88 \mathrm{~d}$ & $0.13 \mathrm{~d}$ \\
\hline
\end{tabular}

Hal ini dapat terjadi karena kita ketahui bahwa penambahan bahan organik, dalam hal ini berupa arang aktif dapat meningkatkan $\mathrm{pH}$ tanah. Seperti diungkapkan (Atmojo, 2003) bahwa bahan organik dapat berperan sebagai buffer pada $\mathrm{pH}$ tanah. Pengaruh penambahan bahan organik terhadap $\mathrm{pH}$ tanah sangat tergantung pada tingkat kematangan bahan organik yang ditambahkan dan juga jenis tanahnya. Selain itu bahan organik juga dapat menyumbangkan gugus- gugus fungsional seperti gugus karboksil $\left(\mathrm{COOH}^{-}\right)$dan fenolik $\left(\mathrm{OH}^{-}\right)$yang berasal dari humus bahan organik. Dari gugus fungsional tersebut secara tidak langsung dengan adanya ion $\mathrm{OH}^{-}$tersebut maka $\mathrm{pH}$ akan semakin meningkat sedangkan penurun $\mathrm{pH}$ terjadi jika adanya ion $\mathrm{H}^{+}$yang jumlahnya semakin banyak.

Hasil analisis kadar air terlihat bahwa perlakuan pemberian bahan amelioran cenderung lebih tinggi dibandingkan perlakuan tanpa amelioran. Perlakuan kompos cenderung menunjukan kadar air yang lebih tinggi dibandingkan perlakuan yang lain. Hal ini karena diketahui bahwa pemberian bahan amelioran dapat meningkatkan kelembaban dan mengurangi terjadinya evapotranspirasi pada media pasir. Sejalan dengan yang diungkapkan (Hudson, 1994) bahwa korelasi positif terjadi dengan semakin banyak kandungan bahan organik yang ditambahkan kedalam tanah maka akan semakin meningkatkan volume kadar air pada kapasitas lapang. Selain itu, pemberian arang aktif secara tidak langsung menyebabkan terjadinya peningkatan kapasitas menahan air tanah (Jeffery et al., 2011). Arang aktif memiliki kemampuan dalam mempertahankan air dalam pori-pori yang ada, selain itu juga membantu terjadinya aliran permukaan saat terjadi hujan karena air dapat dengan mudah masuk ke dalam tanah (Asai et al., 2009). Beberapa penelitian telah menyebutkan bahwa dengan penambahan arang aktif dapat meningkatkan nilai tambah bagi lahan pertanian(Glaser et al., 2002; Lehmann, 2007; Marris, 2006; Warnock et al., 2007) salah satunya yaitu peningkatan dalam kapasitas menahan air (Kammann et al., 2012; Laird et al., 2010). Penelitian (Peake et al., 2014) mengungkapkan bahwa aplikasi arang aktif dapat meningkatkan kapasitas air yang tersedia sebesar lebih dari 22\%. Lebih lanjut (Nelissen et al., 2015) menjelaskan bahwa aplikasi biochar mampu meningkatkan kapasitas air yang tersedia dari 0,12 sampai $0,13 \mathrm{~m}^{3} \cdot \mathrm{m}^{-3}$.

Berdasarkan hasil analisis $\mathrm{C}$-organik dan $\mathrm{N}$-total dapat dilihat bahwa pada perlakuan pemberian bahan amelioran berupa kombinasi arang aktif dan kompos menunjukkan perbedaan yang nyata. Peningkatan kandungan $\mathrm{C}$-organik dan $\mathrm{N}$-total tersebut dapat diperoleh dari bahan organik berupa kompos yang ditambahkan. Seperti yang dikemukakan (Mandey et al., 2010) bahwa kompos aktif organik yang dihasilkan dapat menyumbangkan beberapa unsur hara yang dibutuhkan oleh pertumbuhan tanaman seperti N, P, K, $\mathrm{Ca}, \mathrm{Mg}$ serta meningkatkan kadar air dan $\mathrm{pH}$. Walaupun kita ketahui bahwa unsur hara yang disumbangkan tersebut jumlahnya cukup kecil, namun tidak dapat dipungkiri bahwa penambahan bahan organik tersebut sangat peting kaitannya.

\section{KESIMPULAN}


Adapun kesimpulan yang dapat diambil dari hasil penelitian yang dilakukan yaitu penggunaan bahan amelioran berupa arang aktif dan kompos dapat memperbaiki sifat-sifat tanah pasir antara lain $\mathrm{pH}$, kadar air, $\mathrm{C}$-organik, dan $\mathrm{N}$-total. Sedangkan, pengaruh pertumbuhan tertinggi terhadap tanaman caisim ditunjukkan pada perlakuan PK yaitu berturut-turut 9.86 gram. Sedangkan pada pertumbuhan akar tanaman tertinggi ditunjukkan pada perlakuan PKA sebesar 1.07 gram. Secara umum penggunaan amelioran pada penelitian ini memberikan pengaruh yang baik terhadap perubahan sifat tanah berpasir dan pertumbuhan pada tanaman caisim. Perlakuan arang aktif dan kompos dapat dijadikan sebagai bahan amelioran namun dengan jumlah yang relatif cukup besar dalam kaitan sebagai amelioran.

\section{DAFTAR PUSTAKA}

Asai, H., Samson, B., Stephan, H., Songyikhangsuthor, K., Homma, K., Kiyono, Y., Inoue, Y., Shiraiwa, T., Horie, T., 2009. Biochar amendment techniques for upland rice production in Northern Laos: 1. Soil physical properties, leaf SPAD and grain yield. F. Crop. Res. 111, 81-84.

Atmojo, S.W., 2003. Peranan Bahan Organik terhadap Kesuburan Tanah dan Upaya Pengelolaannya. Sebel. Maret Univ. Press 36.

Balai Penelitian dan Pengembangan Pertanian, 2006. Sifat Fisik Tanah dan Metode Analisisnya. Balai Besar Sumber Daya Lahan Pertanain, Bogor.

Brady, N., 1990. The Nature and Properties of Soils, Tenth. ed. MacMillan Publishing Company, New York.

Cahyani, V., 1996. Pengaruh Inokulasi Mikorisa Vesikular-Arbuskular dan Perimbangan Takaran Kapur Dengan Bahan Organik Terhadap Pertumbuhan Tanaman Jagung Pada Tanah Ultisol Kentrong. Universitas Gajah Mada.

Eghball, B., Ginting, D., Gilley, J.E., 2004. Residual effects of manure and compost applications on corn production and soil properties. Biol. Syst. Eng. Publ. 96, 442-448.

Farooq, M., Wahid, A., Kobayashi, N., Fujita, D., Basra, S., 2009. Plant drought stress : effects , mechanisms and management To cite this version: Review article. Agron. Sustain. Dev. Springer Verlag 29, $185-212$.

Glaser, B., Lehmann, J., Zech, W., 2002. Ameliorating physical and chemical properties of highly weathered soils in the tropics with charcoal - A review. Biol. Fertil. Soils 35, 219-230.

Gusta, A.R., Kusumastuti, A., Parapasan, Y., 2014. Pemanfaatan Kompos Kiambang dan Sabut Kelapa Sawit sebagai Media Tanam Alternatif pada Prenursery Kelapa Sawit (Elaeis guineensis Jacq .). J. Pertan. Terap. 15, 151-155.

Hudson, B., 1994. Soil organic matter and available water capacity. J. Soil Water Conserv. 49, 189-194.

Jeffery, S., Verheijen, F., van der Velde, M., Bastos, A., 2011. A quantitative review of the effects of biochar application to soils on crop productivity using meta-analysis. Agric. Ecosyst. Environ. 144, 175-187.

Kammann, C., Ratering, S., Eckhard, C., Müller, C., 2012. Biochar and hydrochar effects on greenhouse gas (carbon dioxide, nitrous oxide, and methane) fluxes from soils. Jounal Environ. Qual. 41, 1052-66.

Laird, D., Fleming, P., Wang, B., Horton, R., Karlen, D., 2010. Biochar impact on nutrient leaching from a Midwestern agricultural soil. Geoderma 158, 436-442.

Lehmann, J., 2007. Bio-energy in the black. Front. Ecol. Environ. 5, 381-387. 
Priyadi dkk : Aplikasi Kompos dan Arang Aktif Sebagai Bahan Amelioran di Tanah Berpasir...

Mandey, L., Anni, E., Kandou, Tarrore, J., 2010. The Utilization of Decomposers on the Agricultural waste to Produce the Green Product of Organic Active Compost. J. Lasallian 7.

Marris, E., 2006. Putting the carbon back: Black is the new green. Nature 442, 624-626.

Mizuta, K., Matsumoto, T., Hatate, Y., Nishihara, K., Nakanishi, T., 2004. Removal of nitrate-nitrogen from drinking water using bamboo powder charcoal. Bioresour. Technol. 95, 255-257.

Nelissen, V., Ruysschaert, G., Manka'Abusi, D., D’Hose, T., De Beuf, K., Al-Barri, B., Cornelis, W., Boeckx, P., 2015. Impact of a woody biochar on properties of a sandy loam soil and spring barley during a two-year field experiment. Eur. J. Agron. 62, 65-78.

Peake, L., Reid, B., Tang, X., 2014. Quantifying the influence of biochar on the physical and hydrological properties of dissimilar soils. Geoderma 235, 182-190.

Prastiwi, D., 2013. Pemanfaatan Arang Aktif sebagai Carrier Unsur Hara Mikro dalam Pembuatan Pupuk Lambat Tersedia. Institut Pertanian Bogor.

Rachim, D., Arifin, M., 2013. Klasifikasi Tanah di Indonesia. Pustaka Reka Cipta, Bogor.

Scholes, M., Swift, M., Heal, O., Sanchez, P., Ingram, J., Dalal, R., 1994. Soil Fertility Research in Response to The Demand for Sustainability, The Biolog. ed. Jhon Wiley and Sons, Chichester United Kingdom.

Stevenson, F., 1982. Humus Chemistry, Genesis, Composition, Reaction, Second. ed. John Wiley and Sons, New York.

Warnock, D.D., Lehmann, J., Kuyper, T.W., Rillig, M.C., 2007. Mycorrhizal responses to biochar in soil Concepts and mechanisms. Plant Soil 300, 9-20.

Yamato, M., Okimori, Y., Wibowo, I., Anshori, S., Ogawa, M., 2006. Effects of the application of charred bark of Acacia mangium on the yield of maize, cowpea and peanut, and soil chemical properties in South Sumatera, Indonesia. Soil Sci. Plant Nutr. 52, 489-495.

Yao, Y., Bin, G., Ming, Z., Mandu, I., Andrew, R., 2012. Effect of biochar amendment on sorption and leaching of nitrate, ammonium, and phosphate in a sandy soil. Chemosphere 89, 1467-1471. 